\title{
Disclosing genetic research results: experiences of the Colon Cancer Family Registry
}

Louise Keogh $^{1 *}$, Douglass Fisher ${ }^{2}$, Sheri Schully ${ }^{3}$, Jan Lowery ${ }^{4}$, Dennis Ahnen ${ }^{5}$, Judi Maskiell ${ }^{6}$, Noralane Lindor ${ }^{7}$, John Hopper ${ }^{8}$, Terrilea Burnett ${ }^{9}$, Spring Holter ${ }^{10}$, Sheri Sheinfeld Gorin ${ }^{11}$, Pam Sinicrope ${ }^{12}$,

for the Colon Cancer Family Registry

From 14th Annual Meeting of the Collaborative Group of the Americas on Inherited Colorectal Cancer

Dallas, TX, USA. 12-13 October 2010

\section{Background}

Literature on the ethics of returning research-generated genetic results to research participants has not reported on the practical experience of this activity. The Colon Cancer Family Registry (Colon CFR) has recruited participants from the US, Canada, Australia and New Zealand. Colon CFR-wide molecular testing has identified deleterious germline mutations in a DNA mismatch repair (MMR) gene for members of
424 families (153 MLH1, 206 MSH2, 39 MSH6, 26 PMS2). Carriers of mutations in these genes are at high risk of colorectal, endometrial and other cancers.

\section{Aim}

To document our diverse experiences in delivering clinically important genetic results and the uptake of genetic results by participants.

Table 1 Protocols for returning genetic results

\begin{tabular}{|c|c|c|c|c|}
\hline Steps in the protocol & Ontario & Mayo & Australasia & Hawaii \\
\hline $\begin{array}{l}\text { When do sites inform participants that genetic results } \\
\text { may be available }\end{array}$ & At enrolment & At enrolment & At enrolment & $\begin{array}{l}\text { When results } \\
\text { available }\end{array}$ \\
\hline Who provides counseling (Genetic Counselor $=\mathrm{GC}$ ) & $\begin{array}{l}\text { GC shared by study and } \\
\text { hospital }\end{array}$ & MD or GC & $\begin{array}{l}\text { government-funded GC } \\
\text { service }\end{array}$ & $\begin{array}{l}\text { GC employed by } \\
\text { study }\end{array}$ \\
\hline Number of sessions & 2 & 2 & 2 & 2 \\
\hline Mode of delivery of genetic results & In person & $\begin{array}{l}\text { Telephone \& } \\
\text { mail }\end{array}$ & In person & In person \\
\hline
\end{tabular}

Table 2 Uptake of genetic results

\begin{tabular}{lcccc}
\hline & Australasia & Mayo & Ontario & Hawaii \\
$(\mathbf{1 9 9 9 - 2 0 0 9 )}$ & $(\mathbf{2 0 0 8 - 2 0 1 0 )}$ & (1998-2010) & (1998-2010) \\
\hline MMR mutation results available & 805 & 185 & $260^{*}$ & $17^{*}$ \\
Had genetic counselling & 504 & 145 & 197 & 12 \\
Received results & 493 & 144 & 179 & 9 \\
Decision pending & 15 & 12 & 23 & 3 \\
Uptake & $61 \%$ & $78 \%$ & $69 \%$ & $53 \%$ \\
\hline
\end{tabular}

*Probands only.

\footnotetext{
* Correspondence: I.keogh@unimelb.edu.au

${ }^{1}$ Centre for Women's Health, Gender and Society, University of Melbourne,

Melbourne, Victoria, Australia

Full list of author information is available at the end of the article
}

\section{Ciomed Central}

C 2011 Keogh et al; licensee BioMed Central Ltd. This is an open access article distributed under the terms of the Creative Commons Attribution License (http://creativecommons.org/licenses/by/2.0), which permits unrestricted use, distribution, and reproduction in any medium, provided the original work is properly cited. 


\section{Methods}

When a deleterious MMR gene mutation is identified in a family member, predictive testing is conducted on all enrolled relatives of the carrier, and a letter offering to disclose this information is sent to all family members. If participants choose to receive their results, genetic counseling is provided to participants free of charge. Protocols for the four sites currently offering to return genetic results are shown in Table 1.

\section{Results}

Uptake of genetic test results by participants of families with MMR gene mutation results available ranged from 53-78\%, $(\mathrm{p}=0.0001)$ (see Table 2$)$.

\section{Discussion}

The variation in uptake of genetic information could be related to the variation in the potential for insurance discrimination and/or the differences in the cost to consumers of genetic testing in the research and clinic setting.

\section{Conclusions}

The return of genetic results and collection of uptake data has provided valuable information about the translation of these research findings and has led to translational research proposals. Delivering research-generated genetic results in the research setting, especially when sampling is population-based, provides both challenges and opportunities.

\section{Author details}

${ }^{1}$ Centre for Women's Health, Gender and Society, University of Melbourne, Melbourne, Victoria, Australia. ${ }^{2} F r e d$ Hutchinson Cancer Research Center, Seattle, Washington, USA. ${ }^{3}$ Epidemiology and Genetics Research Program, Division of Cancer Control and Population Sciences, National Cancer Institute, Bethesda, Maryland, USA. ${ }^{4}$ Department of Epidemiology, University of Colorado, USA. ${ }^{5}$ Division of Gastroenterology, University of Colorado, USA. ${ }^{6}$ Centre for Molecular, Environmental, Genetic and Analytic Epidemiology, University of Melbourne, Victoria, Australia. ${ }^{7}$ Department of Medical Genetics, Mayo Clinic, Rochester, Minnesota, USA. ${ }^{8}$ Public Health Sciences, Fred Hutchinson Cancer Research Center, Seattle, Washington, USA. ${ }^{9}$ University of Hawaii, Manoa, Hawaii, USA. ${ }^{10}$ Mount Sinai Hospital, Zane Cohen Centre for Digestive Diseases, Toronto, Ontario, Canada. ${ }^{11}$ Department of Epidemiology, Joseph L. Mailman School of Public Health of Columbia University, New York, New York, USA. ${ }^{12}$ Department of Psychiatry and Psychology, Behavioral Health Research Program, Cancer Center, Mayo Clinic, Rochester, Minnesota, USA.

Published: 10 March 2011

doi:10.1186/1897-4287-9-S1-P18

Cite this article as: Keogh et al:: Disclosing genetic research results: experiences of the Colon Cancer Family Registry. Hereditary Cancer in Clinical Practice 2011 9(Suppl 1):P18.

\section{Submit your next manuscript to BioMed Central} and take full advantage of:

- Convenient online submission

- Thorough peer review

- No space constraints or color figure charges

- Immediate publication on acceptance

- Inclusion in PubMed, CAS, Scopus and Google Scholar

- Research which is freely available for redistribution

Submit your manuscript at www.biomedcentral.com/submit 